\title{
MICROBIAL PRODUCTION OF BIOVANILLIN
}

\section{A. Converti ${ }^{1 *}$; B. Aliakbarian ${ }^{1}$; J.M. Domínguez ${ }^{2}$; G. Bustos Vázquez; ${ }^{3}$ P. Perego ${ }^{1}$}

${ }^{1}$ Department of Chemical and Process Engineering, University of Genoa, Via Opera Pia 15, 16145 Genoa, Italy; ${ }^{2}$ Department of Chemical Engineering, Vigo University (Campus of Ourense), Polytechnical Building, As Lagoas, 32004 Ourense, Spain;

${ }^{3}$ Departamento de Biotecnología, Unidad Académica Multidisciplinaria Mante, Universidad Autónoma de Tamaulipas, Blvd. E.C. Glez, 1201, col. Jardín, 89840 Ciudad Mante, Tamaulipas, México.

\begin{abstract}
This review aims at providing an overview on the microbial production of vanillin, a new alternative method for the production of this important flavor of the food industry, which has the potential to become economically competitive in the next future. After a brief description of the applications of vanillin in different industrial sectors and of its physicochemical properties, we described the traditional ways of providing vanillin, specifically extraction and chemical synthesis (mainly oxidation) and compared them with the new biotechnological options, i.e., biotransformations of caffeic acid, veratraldehyde and mainly ferulic acid. In the second part of the review, emphasis has been addressed to the factors most influencing the bioproduction of vanillin, specifically the age of inoculum, $\mathrm{pH}$, temperature, type of co-substrate, as well as the inhibitory effects exerted either by excess substrate or product. The final part of the work summarized the downstream processes and the related unit operations involved in the recovery of vanillin from the bioconversion medium.
\end{abstract}

Key words: vanillin, bioconversion, review, ferulic acid, Escherichia coli

\section{INTRODUCTION}

Vanillin is an important flavoring and aromatic component that is mainly obtained from the bean or pod of the tropical orchid Vanilla planifolia, and in less extent of Vanilla tahitiensis and Vanilla pompona, which are commonly denominated as "vanilla". Vanilla is produced mainly in Indonesia and Madagascar and China, as summarized in Table 1, published by the Food and Agriculture Organization of the United Nations (26).
Table 1. Amount of vanilla produced in 2008 (FAO-STAT, 2010).

\begin{tabular}{lc}
\hline Country or continent & Production (tons) \\
\hline Indonesia & 3700 \\
Madagascar & 2800 \\
China & 1400 \\
Mexico & 637 \\
Tonga & 150 \\
Uganda & 70 \\
Asia & 5270 \\
Africa & 2970 \\
America & 645 \\
Oceania & 180 \\
European Union & 15 \\
\hline World & 9080 \\
\hline
\end{tabular}

\footnotetext{
*Corresponding Author. Mailing address: Department of Chemical and Process Engineering, University of Genoa, Via Opera Pia 15, 16145 Genoa, Italy.; E-
} mail: converti@unige.it 
However, less than $1 \%$ of the worldwide production of vanillin comes from natural vanilla, because its cost is very high $(1.200-4.000 \$ / \mathrm{kg})$ with respect to that $(<15 \$ / \mathrm{kg})$ of vanillin synthesized by chemical processes $(46,47)$. The high and variable cost of natural vanillin is due to various reasons, including limited availability of vanilla pods, fluctuations in crop yields associated with the climate, political and economic decisions, intensive cultivation, pollination, harvesting and ripening of pods. Since the use of a natural substrate or catalyst could allow the same product to be classified as natural (65), a biotechnological production of this compound is hoped for $(52,54,58,67,85)$.

In the nineteenth century the chemical structure of vanillin was identified, and different processes of vanillin production were developed either by oxidation of coniferin (45), which is found in the tissues of various conifers, or from eugenol. This constituent of clove oil is currently the source of artificial vanillin, which is obtained from the sulfite spent liquor from paper mills $(35,73)$ and coal tar extract (79).

In 1997, the H\&F Florasynth began the production of a vanillin identical to the natural one through a process that consists of two steps, one that leads to ferulic acid and another that turns it into vanillin. Recent research has identified the precursors and almost all enzymes involved in the metabolic pathway for the synthesis of vanillin in vanilla fruit, which could permit the production of synthetic vanilla just by the same way as plants do (53).

Currently, artificial vanilla production is performed at an industrial scale by the controlled oxidation of lignin from wood waste, which results in fatty product subsequently purified by distillation and crystallization.

\section{APPLICATIONS OF VANILLIN}

Along with aromas of citrus and mint, those of vanilla are the most important in the food industry, the world production of vanilla pods being at present more than 9,000 tons, and rising.
Vanillin is widely used as flavoring in sweet foods like cookies, muffins, cakes, ice creams and soft drinks. Because of its antimicrobial and antioxidant properties $(14,23)$, vanillin could be used as food preservative, but this potential use is hampered by its strong smell in the inhibitory concentrations required (28). It can also be used as a precursor in the manufacture of other flavorings. For example, it can be synthesized the zingiberon (main ginger flavoring agent) by condensation reactions, as well as the main component of jasmine oil (trans-jasmonate and (+)-cis-jasmonate) by reaction with heptaldehyde in basic medium and alcohol. It also has non-food uses, such as the implementation of fragrances or pharmaceutical preparations, where it is used as a flavoring agent or as a precursor of drugs among which LDopa, Aldomet and dopamine $(81,82)$.

Synthetic vanillin is used as an intermediate in the production of herbicides, antifoaming agents (35), home products, deodorants, air fresheners and cleaning products such as floor polishes.

\section{PHYSICOCHEMICAL PROPERTIES}

Vanillin is a white solid with a strong smell of vanilla, whose formula is $\mathrm{C}_{8} \mathrm{H}_{8} \mathrm{O}_{3}$. It is an aromatic aldehyde (3methoxy-4-hydroxybenzaldehyde), belonging to the group of simple phenolic compounds (Figure 1). Structurally, its functional groups include aldehyde, ether, and phenol, and their physico-chemical properties are summarized in Table 2.

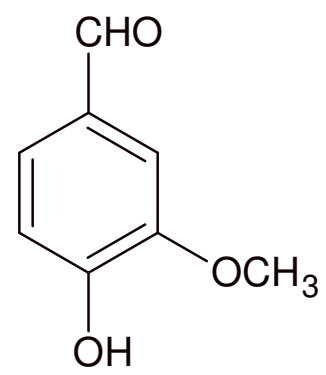

Figure 1. Chemical structure of vanillin. 
Table 2. Physico-chemical properties of vanillin.

\begin{tabular}{lc}
\hline Property & Value \\
\hline Solubility in water at $20^{\circ} \mathrm{C}(\mathrm{g} / \mathrm{L})$ & 10 \\
Molecular weight $(\mathrm{g} / \mathrm{mol})$ & 152.15 \\
Melting point $\left({ }^{\circ} \mathrm{C}\right)$ & $80 / 83$ \\
Boiling point $\left({ }^{\circ} \mathrm{C}\right)$ & $\sim 285$ \\
\hline
\end{tabular}

\section{PRODUCTION TECHNOLOGIES}

Slightly less than $1 \%$ of world production of vanillin comes from natural vanilla; the rest is synthesized by chemical processes, making it cheaper.

\section{Extraction by Leaching}

The processing of vanilla to produce vanillin begins with the curing of freshly harvested pods. The aim of the curing process is to stop the natural vegetative process and to accelerate changes responsible for the formation of aromatic flavor constituents. The curing method differs from one production area to the other, and this can have a major influence on variation in quality and aromatic profile of pods that are traded.

Although there are several ways of curing, all share four main phases:
- Wilt: It avoids post-harvest vegetative growth and promotes the enzymatic reactions responsible for the production of aroma and flavor. It is recognized by the appearance of brown spots on the pods.

- Sweating: In this phase the temperature is raised to promote the enzymatic reactions and rapid initial drying so as to prevent harmful fermentation.

- Drying: This process is performed at room temperature until the pods reach a third of their initial weight.

- Packaging: The pods are stored in closed boxes for a period of three months, which may stretch up to reaching the aroma and flavor desired.

Vanillin, which is linked to glycosidic molecules in the green pods, separates from them during the ripening process due to drying and heat; the vanillin $\beta$-D-glucoside is enzymatically hydrolyzed to give glucose and vanillin (Figure 2).

The production of vanillin is very laborious and expensive, so alternative routes are sought. Recently, Jadhav et al. (37), in their attempt to optimize vanillin extraction from cured vanilla pods, reported that the use of ultrasonic irradiation resulted in significant intensification of vanillin extraction in Soxhlet using ethanol as the solvent, being able to release no less than $140 \mathrm{ppm}$ vanillin when the extraction time was reduced from 8 to $1 \mathrm{~h}$ and the temperature from $95{ }^{\circ} \mathrm{C}$ to room temperature at almost the same solvent-to-solute proportion $(66.7 \mathrm{ml} / \mathrm{g})$.<smiles>COc1cc(OC2C(Oc3ccc(C=O)cc3OC)OCC(O)C(O)C2O)ccc1C=O</smiles>

Figure 2. Separation of vanillin during ripening. 


\section{Chemical Synthesis}

Between 1874-1875, it was developed a process of synthetic vanillin production from eugenol (Figure 3 ) that was used until the end of 1920.

The detection of a slight vanillin odor in a liquor made from sulfite pulping, which was subsequently confirmed by performing a pyrolysis of the dry residue of this liquor (29), suggested that vanillin could be produced from lignin-rich wastes. Later studies tried to establish its production from lignin-rich dry pulp $(34,36)$, but preliminary treatments were found to be too laborious.

Finally, it was demonstrated that vanillin recovered from the sulfite spent liquor comes from guaiacyl units of lignin solubilized by alkaline oxidation during softwoods pulping. Its commercial production started from an aqueous solution of the liquor containing sodium vanillate, which was purified via carbonyl sulfate by addition of $\mathrm{H}_{2} \mathrm{SO}_{3}$.

\section{Biotransformation of Caffeic Acid and Veratraldehyde}

The biotransformation of caffeic acid and veratraldehyde is also reported in the literature as a possible alternative way to produce vanillin. To this purpose, the roots of Capsicum frutescens resulted to be an efficient source of caffeic acid (70). This biotransformation, which is illustrated in Figure 4, includes a first step of vanillin formation from caffeic acid and a subsequent oxidation of vanillin into vanillic acid. The biosynthetic pathway implying veratraldehyde as a starting carbon source is shown in Figure 5. In this case the substrate is demethylated enzymatically to form vanillin and $p$ hydroxybenzoic acid, the former being oxidated into vanillic acid successively (70). In both cases, the research efforts to get an effective accumulation of vanillin should be addressed to the way of hindering or suppressing the final vanillin-tovanillic acid oxidation step.

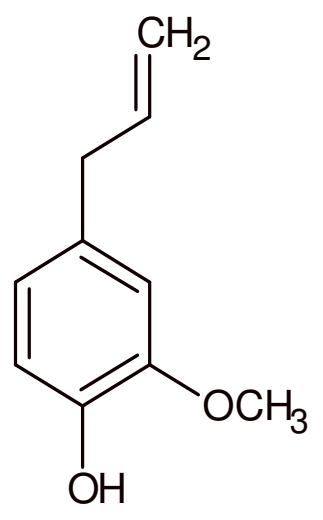

Eugenol

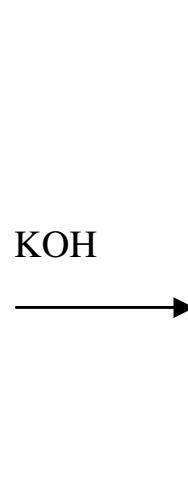

Isoeugenol<smiles>COc1cc(C=O)ccc1O</smiles>

Vanillin

Figure 3. Production of vanillin via eugenol. 
<smiles>O=C(O)COc1cccc(O)c1</smiles>

Caffeic acid<smiles>COc1cc(/C=C/C(=O)O)ccc1O</smiles>

Ferulic acid<smiles>COc1cc(C(=O)O)ccc1O</smiles>

Vanillin
Vanillic acid<smiles>COc1cc(CN)ccc1O</smiles>

Vanillylamine

Figure 4. Biosynthetic pathways of vanillin, vanillyl alcohol and vanillic acid production from caffeic acid.

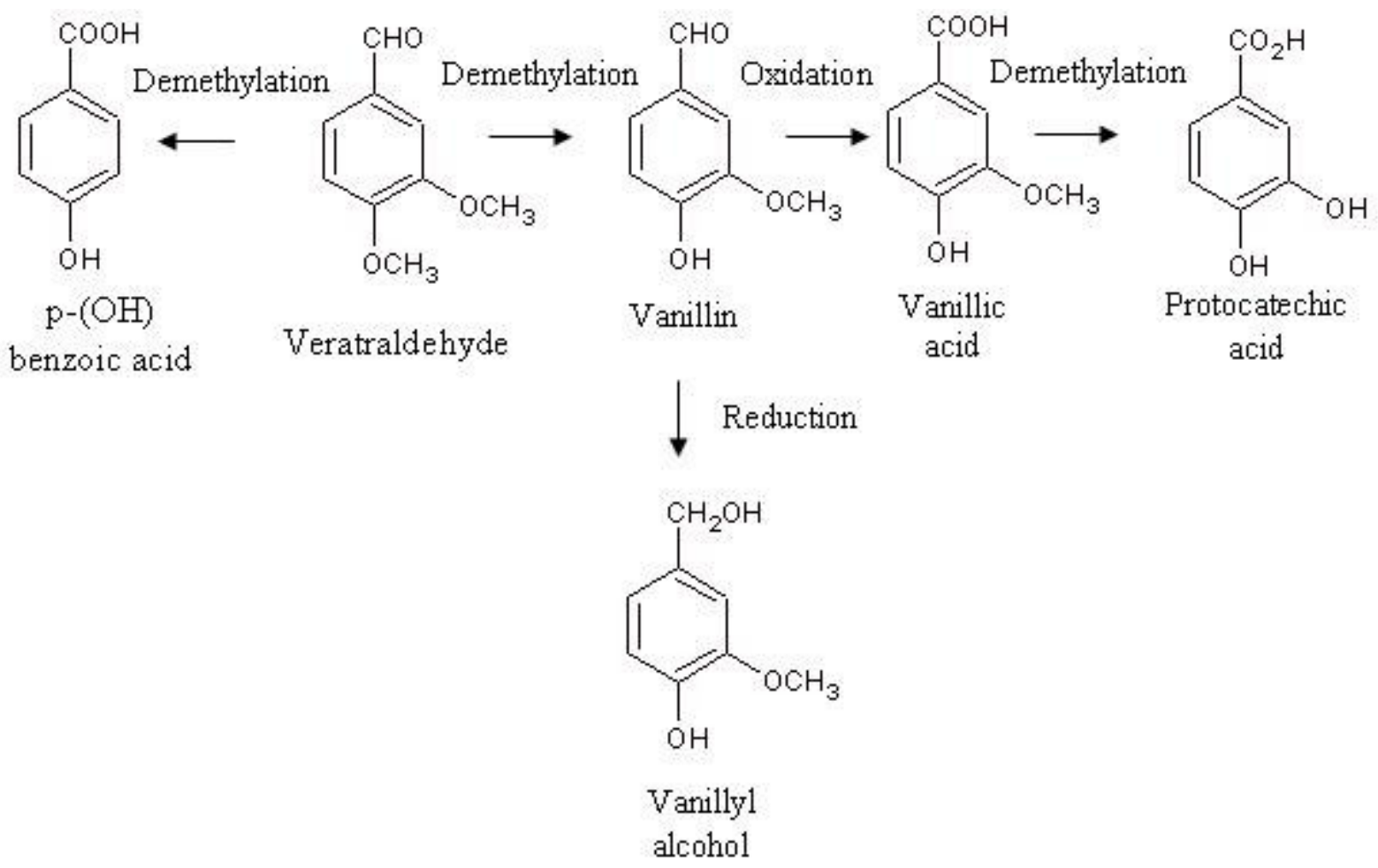

Figure 5. Biosynthetic pathways of vanillin, vanillyl alcohol and vanillic acid production from veratraldehyde. 


\section{Fermentation}

The big difference between the prices of natural and synthetic vanillin, the increased demand for "natural" and "healthy" flavors have stimulated a great interest of the flavorings industry to produce natural vanillin by bioconversion from other natural sources. This common orientation in the production of flavors and fragrances was analyzed extensively $(15,32,33,42,61)$.

To make the process economically viable, it is necessary to find a precursor chemically close to vanillin, cheap and easily available. Ferulic acid, a widely-known natural phenolic compound from lignin degradation by fungi (40) and bacteria (7), was deeply studied as vanillin precursor (61). As highlighted by Di Gioia et al. (25), the enzymatic hydrolysis is an especially interesting option to dissolve lignin by cleavage of the ester bonds present in lignin-polysaccharide complexes $(27,68,83)$. Free ferulic acid can be obtained from common agricultural residues, grains and beet pulp through a combination of physical and enzymatic treatments (84).

Vaithanomsat and Apiwatanapiwat (78) obtained by steam explosion a Jatropha curcas stem hydrolysate containing $1.55 \mathrm{~g} / \mathrm{L}$ of ferulic acid, which was successfully used as substrate for one-step vanillin production by Aspergillus niger and Pycnoporus cinnabarinus, while Torre et al. (74) optimized the release of ferulic acid $(1.17 \mathrm{~g} / \mathrm{L})$ from corn cobs using $\mathrm{NaOH}$ hydrolysis.

Several bacteria belonging to different genera are able to metabolize ferulic acid as sole carbon source leading to the production of vanillin, vanillic acid and protocatechuic acid as catabolic intermediates $(31,71)$, the most interesting of which being Pseudomonas fluorescens (1, 4, 49).

Interesting concentrations of vanillin were obtained from ferulic acid using the Gram-positive bacteria Amycolatopsis sp. (56) and Streptomyces setonii $(30,48)$. However, since the process optimization is very difficult, the development of new recombinant strains able to produce vanillin is quite attractive.

Recent studies have confirmed that the combination of genes of the feruloyl-CoA synthase and feruloyl-CoA hydratase from Pseudomonas fluorescens BF13 unable different strains of Escherichia coli to produce vanillin from ferulic acid-rich substrates $(3,20,50,85)$. For this purpose, a recombinant plasmid (pBB1) was constructed which is made up of 5,000 bp (8). The donor fragment contains a mutation of the vanillin dehydrogenase (VDH) that prevents vanillin-tovanillic acid oxidation, thus promoting vanillin accumulation during the process of ferulic acid bioconversion (Figure 6).

An earlier study, conducted with several strains of $E$. coli (E. coli DH5a, E. coli JM109, E. coli JM Promega, E. coli Novablu, E. coli SureII, E. coli XL10 Gold), allowed selecting the second one as the best producer, being able to ensure the most interesting combination of vanillin yield and production kinetics as well as product stability (20). Nevertheless, this transformant showed in Luria-Bertani (LB) medium a duplication time more than twice (24) that of the wild type $(0.5 \mathrm{~h})$ under optimal growth conditions in glucose $(13,63)$.

The biotechnological process for vanillin production from various agro-products has been investigated using different microorganisms as biocatalysts. Aspergillus niger I-1472 and Pycnoporus cinnabarinus MUCL39533 were used in a twostep bioconversion using sugar beet pulp (11), maize bran (44), bran oil rice (88), and wheat bran (72) as raw materials.

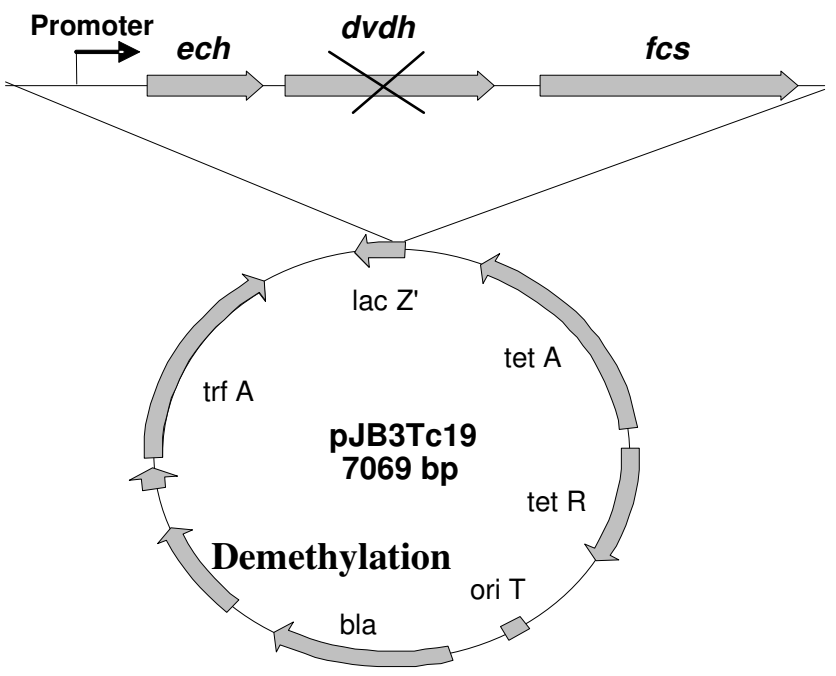

Figure 6. Construction of plasmids pBB1 containing genes from Pseudomonas fluorescens BF13 to produce vanillin from ferulic acid using the vector pJB3Tc19. The plasmid was subsequently transformed into E. coli JM109. 


\section{FACTORS INFLUENCING THE MICROBIAL PRODUCTION OF VANILLIN}

\section{Age of Inoculum}

To maximize the bioconversion yield, the microorganism has to be adapted to the substrate as much as possible (60); to achieve this result, the inoculum must be done once the microorganism has completed its exponential growth phase and before entering the stationary one [ $6 \mathrm{~h}$ in the case of $E$. coli JM109(pBB1)] (76). Previous studies have shown that biomass of this strain under non-proliferating conditions (resting cells) can be recycled up to 4 times without significant loss of bioconversion capacity, and used in a continuous process after immobilization in synthetic spongy material (76).

\section{Acidity}

As is well known, the acidity level is a critical parameter in cell cultures since they can only grow in a narrow range of $\mathrm{pH}$, outside of which the bioconversion yield decreases. The study of the effect of the acidity level on cultures carried out either in presence of $\mathrm{H}_{2} \mathrm{O}_{2}$ at different concentrations or not revealed that decreasing values of $\mathrm{pH}$ below 7.4 accelerated the decay E. coli population $(3,57)$.

\section{Temperature}

All microorganisms have an optimum temperature for growth. E. coli can be classified as a mesophilic microorganism, i.e., its optimum temperature range is between 20 and $40^{\circ} \mathrm{C}$. Previous studies performed with E. coli JM109 (pBB1) cells demonstrated that the optimum growth temperature for this strain is $37^{\circ} \mathrm{C}$. On the other hand, once the microorganism was grown and inoculated, the optimum temperature for carrying out the subsequent ferulic acic-tovanillin bioconversion was $30^{\circ} \mathrm{C}(24,77)$.

\section{Co-substrate}

As detailed in the previous chapter, the production of vanillin occurs through a secondary pathway other than glycolysis, which does not imply any ATP formation. So, the cell needs a carbon source for catabolism, i.e., an energy source that enables its long term-viability in view of possible application in a continuous system. A deep investigation on the components that make up the culture media is, therefore, very important. Rabenhorst (55) demonstrated the importance of yeast extract (YE), casein hydrolyzate and aeration to address the metabolism of eugenol in some isolates of Pseudomonas sp. toward the desired aromas (vanillic acid, ferulic acid and coniferyl alcohol).

Similarly, Torre et al. (75) investigated the effect of different co-substrates (YE, tryptone or LB medium, which contains both ingredients) on the ferulic acid-to-vanillin bioconversion by E. coli JM109 (pBB1), trying to avoid or minimize the formation of other by-products. YE was shown to be a satisfactory stimulating agent, being able to provide, after only $3 \mathrm{~h}$ of bioconversion, a promising vanillin concentration $(84 \mathrm{mg} / \mathrm{L})$, which was $27 \%$ higher than that obtained with tryptone and only $3.6 \%$ lower than with the more expensive LB medium.

\section{Substrate Inhibition}

The concentration of ferulic acid may influence the production of vanillin, both in terms of productivity and yield. A previous study showed that a progressive increase in ferulic acid concentration reduces the specific productivity of vanillin in a way similar to that observed for excess substrate inhibition of alcoholic fermentation $(16,21)$.

\section{Product inhibition}

When the accumulation of the end product of a biochemical pathway stops the synthesis of the desired product, is said to occur product inhibition. The production of vanillin by microorganisms is associated to the formation of a number of compounds such as vanillic acid and vanillyl alcohol, which can act, together with vanillin, as potential inhibitors of the bioconversion, decreasing the amount of ferulic acid addressed to the production of the desired product (51). It is anyhow noteworthy the fact that, having both vanillyl alcohol and vanillic acid practically the same smell as 
vanillin, a biotechnological production of a mixture of these three components could equally be of great interest for the flavor industry (19).

\section{Dissolved Oxygen Concentration and Agitation}

The growth rate of biomass is influenced by agitation and by the coefficient of $\mathrm{O}_{2}$ transfer. Torre et al. (75), to highlight the effect of the former variable on growth, inoculated $E$. coli JM109 (pBB1) in $250 \mathrm{~mL}$ Erlenmeyer flasks simultaneously varying the ratio of volumes of the medium and the flasks from 0.2 to 0.5 and the agitation in the range $100-200 \mathrm{rpm}$. The best conditions for the bioconversion resulted to be a ratio of 0.5 and an agitation of $100 \mathrm{rpm}$. Excess increase in aeration did in fact become deleterious for the bioconversion, probably because the activity of non-specific oxidases oxidized a significant portion of vanillin to vanillic acid, thereby reducing the product yield (75).

\section{Pre-cultivation of the Microorganism}

The use of only one step of pre-cultivation can significantly reduce the bioconversion time, likely because of earlier adaptation to bioconversion conditions, thus reducing the overall costs of its potential industrial application. Rivas Torres et al. (60) investigated the possibility of omitting the second step of pre-cultivation on the bioconversion of ferulic acid to vanillin using E. coli JM109(pBB1). The results of their experiments highlighted that, when biomass from the first stage of growth in LB medium was directly employed in the bioconversion medium, vanillin volumetric and specific productivities increased from 1.7 to $3.6 \mathrm{mg} / \mathrm{Lh}$ and from 3.4 to $7.1 \mathrm{mg} / \mathrm{g}_{\mathrm{DM}} \mathrm{h}$, respectively using $0.5 \mathrm{~g}_{\mathrm{DM}} / \mathrm{L}$ of biomass.

\section{VANILLIN RECOVERY}

Vanillin, like several other aromatic aldehydes, is commonly considered toxic to microorganisms (51); therefore, it is difficult to get high volumetric yields of this compound. It is therefore worth not only selecting strains able to tolerate high vanillin concentrations, but also finding out bioconversion ways to remove the formed aldehyde from the reaction system. For this reason and because of the low product concentrations in the bioconversion medium, also in the case of vanillin the major drawback that limits possible real-scale applications is, from both the technical and economic viewpoints, the operation at intermediate substrate concentration.

Since the international legislation about food products requires the exclusive use of physical separation operations for the recovery of natural flavors, vanillin isolation and purification can be performed by extraction, vacuum distillation and multi-stage re-crystallization from aqueous solutions and ultrafiltration $(10,12)$.

The crystallization is, perhaps, the most widespread technique utilized for the recovery of bioproducts from fermentation or bioconversion media; however, in the case of vanillin, it will become competitive only when it will be possible to obtain the product with much higher yields with respect to those reported in the literature (54), the only exceptions being the high concentrations of vanillin $(10 \mathrm{~g} / \mathrm{l})$ obtained with Amycolatopsis sp. (56) and Streptomyces setonii (48). The minimum concentration of vanillin to allow for its effective crystallization is in fact considered to be just $10 \mathrm{~g} / \mathrm{l}$ at $20^{\circ} \mathrm{C}(17)$, which strongly influences the recovery process.

The recovery of biomolecules by two-phase systems utilizing an aqueous phase and an organic phase is promising $(18,59,62,64)$, even if the selection of new microorganisms with greater resistance to organic solvents (2) seems to be necessary when this technique is employed for the continuous removal of the product. Interesting two-phase extraction processes, employing either sulphydryl compounds, such as dithiothreitol, dithioerythritol, glutathione, or L-cysteine (43), or alkaline $\mathrm{KOH}$ solutions (5), are reported in the literature for the recovery of vanillin as well as for its separation from other aromatic substances coming from the hydrolysis of lignocellulosics, among which ferulic acid.

The pervaporation, as a technique for the recovery and/or purification of volatile solutes on hydrophobic membranes and desorption into a vapor phase, has been described for numerous bioproducts $(6,80)$. In particular, its use for vanillin recovery from aqueous solutions is suggested by the excellent 
permeability of some types of membranes toward aromatic hydrocarbons (9). Promising results have been obtained in this field by vanillin adsorption and pervaporation from bioconverted media using polyether-polyamide copolymer membranes $(10,89)$.

The selective adsorption of a given product can enhance the production by avoiding further undesired reactions (83). For example, the use of polystyrene resins allowed minimizing the reduction of vanillin to vanillyl alcohol in Phanerochaete chrysosporium cultures (69). Recently, Zhang et al. (87) reported the use of macroporous adsorption resins with crosslinked-polystyrene framework to recover dissolved vanillin from aqueous solutions. The highest adsorption capacity was $416 \mathrm{mg} / \mathrm{g}$ (vanillin/resin), and the recovery efficiency was more than $95 \%$ when using 3-5 bed volumes of absolute ethanol that is an acceptable solvent in food grade application. The resin was used repeatedly by simple regeneration, and its adsorption capacity kept almost unchanged. Alternatively, Knuth and Sahai (41) described a process for the continuous removal of vanillin using activated charcoal as an adsorbent, but the cost of this material is notoriously too high for industrial purposes.

Membrane processes have all the requirements needed to act as key separation units in biorefineries due to their excellent fractionation capability, low chemical consumption and low energy requisites (38). The ultrafiltration technique has been evaluated to recover vanillin from Kraft lignin oxidation (86). Membrane technologies allow separating molecules that normally do not permeate the membrane and are collected in the "retentate" fraction from those that permeate the membrane and are collected in the "permeate" fraction. Retention of the concentrated molecules strongly depends on the size of membrane pores, though shape and chemical nature of molecules (physico-chemical interactions) often play an important role as well, especially in those processes, like nanofiltration and reverse osmosis, involving molecules of compounds with very low molecular weight. Recently, Sciubba et al. (66) evaluated the potential of using membrane contactor (MC) technology for the recovery of vanillin from bioconversion broths in view of an integrated bioconversion separation process.

A filtration devise usually consists of a system with plate or modular membrane; in both cases, the permeate flux is radial with respect to the flux so as to reduce the membrane fouling, with consequent reduction of the filtration effectiveness (18). The most typical parameters involved in a membrane process are the permeate flowrate, which defines the filtering performance of the membrane, the working pressure, which is strictly correlated with the filtration rate, and the recirculating flowrate of the waste (39).

Cost analysis of this kind of processes is basically depending on the working pressure and on the average membrane life. Lastly, the concentration yield indicates the degree of concentration of the treated waste. In fact, among all the technologies that can be applied to this purpose, the use of membrane separation systems comes out to be very interesting and attractive thanks to the effectiveness and low costs involved (22). This would represent a simple way both to recover vanillin and to recirculate the residual substrate. Coupling the extraction to the biocatalytic system is expected to allow operating continuously so as to achieve higher bioconversion productivity.

\section{REFERENCES}

1. Andreoni, V.; Bemasconi, S.; Bestetti, G. (1995). Biotransformation of ferulic acid and related compounds by mutant strains of Pseudomonas fluorescens. Appl. Microbiol. Biotechnol. 42, 830-835.

2. Aono, R. (1998). Improvement of organic solvent tolerance level of Escherichia coli by overexpression of stress-responsive genes. Extremophiles 2, 239-248.

3. Barghini, P.; Di Gioia, D.; Fava, F.; Ruzzi, M. (2007). Vanillin production using metabolically engineered Escherichia coli under nongrowing conditions. Microb Cell Fact. 6, 13-23.

4. Barghini, P.; Montebove, F.; Ruzzi, M.; Schiesser, A. (1998). Optimal conditions for bioconversion of ferulic acid into vanillic acid by Pseudomonas fluorescens BF13 cells. Appl. Microbiol. Biotechnol. 49, 309-314.

5. Barraclough, A.J.; Cheetham, P.S.J.; Westcott, R.J. (1994). Production of vanillin. World Pat. 9413614.

6. Bengtson, G., Böddeker, K.W. (1995). Extraction of bioproducts with 
homogeneous membranes. In: Étiévant, P.; Schreier, P. (eds.). Biovanillin, INRA Ed., Paris, p. 393-403.

7. Betts, W.B.; Dart, R.K. (1988). Screening of fungi and bacteria for their ability to degrade insoluble, lignin-related aromatic compounds. Microbios 55, 85-93.

8. Blatny, J.M.; Brautaset, T.; Winther-Larsen, H.C.; Haugan, K.; Valla, S. (1997). Construction and use of a versatile set of broad-host-range cloning and expression vectors based on the RK2 replicon. Appl. Environ. Microbiol. 63, 370-379.

9. Böddeker, K.W.; Bengtson, G.; Bode, E. (1990). Pervaporation of low volatility aromatics from water. J. Membrane Sci. 53, 143-158.

10. Böddeker, K.W.; Gatfield, I.L.; Jähnig, J.; Schorm, C. (1997). Pervaporation at the vapor pressure limit: vanillin. J. Membrane Sci. 137, 155-158.

11. Bonnin, E.; Brunel, M.; Gouy, Y.; Lesage-Meessen, L.; Asther, M.; Thibault, J-F. (2001). Aspergillus niger I-1472 and Pycnoporus cinnabarinus MUCL39533, selected for the biotransformation of ferulic acid to vanillin, are also able to produce cell wall polysaccharidedegrading enzymes and feruloyl esterases. Enzyme Microb. Technol. 28, 70-80.

12. Borges da Silva, E.A.; Zabkova, M.; Araújo, J.D.; Cateto, C.A.; Barreiro, M.F.; Belgacem, M.N.; Rodrigues, A.E. (2009). An integrated process to produce vanillin and lignin-based polyurethanes from Kraft lignin. Chem. Eng. Res. Des. 87, 1276-1292.

13. Brock, T.D.; Madigan, M.D.; Martinko, J.M.; Parker, J. (1995). Microbiologia. Città Studi Edizioni, Milan.

14. Burri, J.; Graf, M.; Lambelet, P.; Löiger, J. (1989). Vanillin: more than a flavouring agent-a potent antioxidant. J. Sci. Food Agric. 48, 49-56.

15. Cheetham, P.S.J. (1993). The use of biotransformation for the production of flavours and fragrances. Trends Biotechnol. 11, 478-488.

16. Ciftci, C.; Constantinides, A.; Wang, S.S (1983). Optimization of conditions and cell feeding procedures for alcohol fermentation. Biotechnol. Bioeng. 25, 2007-2023.

17. Clark, G.S. (1990). Vanillin. Perf. Flavor 15, 45-54.

18. Converti, A. (2008). Recupero di prodotti biotecnologici. In: Donadio, S.; Marino, G. (eds). Biotecnologie Microbiche. Casa Editrice Ambrosiana, Milan, Italy, p. 413-445.

19. Converti, A. (2009). Aprovechamiento de residuos agroindustriales para la generación de aditivos alimentarios: Tratamiento de las materias primas y estudios metabólicos. Vigo, Spain, 240p. (PhD Dissertation. Faculty of Sciences. Universidade de Vigo).

20. Converti, A.; De Faveri, D.; Perego, P.; Barghini, P.; Ruzzi, M.; Sene L. (2003). Vanillin production by recombinant strains of Escherichia coli. Braz. J. Microbiol. 34(suppl.), 108-110.

21. Converti, A.; Perego, P.; Del Borghi, M.; Parisi, F.; Ferraiolo, G. (1986). Kinetic considerations about the study of alcoholic fermentations of starch hydrolysate. Biotechnol. Bioeng. 28, 711-717.

22. Coulson, J.M.; Richardson, J.F. (1991). Chemical Engineering, Vol. 2, 4th Edn. Pergamon, Oxford, UK.
23. Davidson, P.M.; Naidu. A.S. (2000). Phyto-phenols. In: Naidu A.S. (ed.). Natural Food Antimicrobial Systems. CRC Press LLC, Boca Raton, London, p. 265-294.

24. De Faveri, D.; Torre, P.; Aliakbarian, B.; Domínguez, J.M.; Perego, P.; Bustos, G., Converti A. (2008). Conversión microbiana de ácido ferúlico a vainillina, In: Bustos Vázquez, G.; Velázquez de la Cruz, E.; Rangel Torres, E.; Compeán Ramírez, E.; Campos Leal, J.R. (eds.). Aprovechamiento Biotecnológico de Productos Agropecuarios II. Plaza y Valdés, S.A. de C.V., México, p.181-203.

25. Di Gioia, D.; Sciubba, L.; Setti, L.; Luziatelli, F.; Ruzzi, M.; Zanichelli, D.; Fava, F. (2007). Production of biovanillin from wheat bran, Enzyme Microb. Technol. 41, 498-505.

26. FAO-STAT (2010). FAO Statistical Database, http://www.fao.org. Accessed 17 February 2010.

27. Faulds, C.B.; Mandatari, G.; Lo Curto, R.B.; Bisognano, G.; Waldron, K.W. (2004). Arabinoxylan and mono- and dimeric ferulic acid release from brewer's and wheat bran by feruloyl esterases and glycosyl hydrolases from Humicolar insolens. Appl. Microbiol. Biotechnol. 64, 644-650.

28. Gould, G.W. (1996). Industry perspectives on the use of natural antimicrobials and inhibitors for food applications. J. Food Prot. suppl. $59,82-86$.

29. Gräfe V. (1904). Untersuchungen uber die Holzsubstanz von chemischphysiologischen Standpunkte. Monatsh. Chem. Wissen. 25, 987.

30. Gunnarsson, N.; Palmqvist, E.A. (2006). Influence of $\mathrm{pH}$ and carbon source on the production of vanillin from ferulic acid by Streptomyces setonii ATCC 39116. Develop. Food Sci. 43, 73-76.

31. Gurujeyalakshmi, G.; Mahadevan, A. (1987). Dissimilation of ferulic acid by Bacillus subtilis. Curr. Microbiol. 16, 69-73.

32. Hagedorn, S.; Kaphammer, B. (1994). Microbial biocatalysis in the generation of flavour and fragrance chemicals. Annu. Rev. Microbiol 48, 773-800.

33. Häusler, A.; Münch, T. (1997). Microbial production of natural flavours, ASM News 63, 551-559.

34. Hibbert, H.; Tomlinson Jr, G.H. (1936). Manufacture of vanillin from waste sulfite pulp liquor. U.S. Patent 2069185.

35. Hocking, M.B. (1997). Vanillin: synthetic flavouring from spent sulfite liquor. J. Chem. Educ. 74, 1055-1059.

36. Howard, G.C. (1925). U.S. Patent 1551882.

37. Jadhav, D.; Rekha, B.N.; Gogate, P.R.; Rathod, V.K. (2009). Extraction of vanillin from vanilla pods: A comparison study of conventional soxhlet and ultrasound assisted extraction. J. Food Eng. 93, 421-426.

38. Jönsson, A.S.; Nordin, A.K.; Wallberg, O. (2008). Concentration and purification of lignin in hardwood kraft pulping liquor by ultrafiltration and nanofiltration. Chem. Eng. Res. Des. 86, 1271-1280.

39. Kilikian, B.V.; Pessoa Jr., A. (2001). Purificação de produtos biotecnológicos. In: Schmidell, W.; Lima, U.A.; Aquarone, E.; Borzani, W. (eds). Biotecnologia Industrial. Engenharia Bioquímica, Vol. 2., $1^{\text {st }}$ Ed. Editora Edgard Blücher, São Paulo, Brazil, p. 493. 
40. Kirk, T.K. (1971). Effects of microorganisms on lignin. Annu. Rev. Phytopatol. 9, 185-210.

41. Knuth, M.E.; Sahai, O.P. (1991). Flavour composition and method. World Pat. 8900820.

42. Krings, U.; Berger, R.G. (1998). Biotechnological production of flavours and fragrances. Appl. Microbiol. Biotechnol. 49, 1-8.

43. Labuda, I.M.; Goers, S.K.; Keon, K.A. (1992). Bioconversion process for the production of vanillin. U.S. Pat. 5128253

44. Lesage-Meessen, L.; Lomascolo, A.; Bonnin, E.; Thibault, J.F.; Buleon, A.; Roller, M.; Asther, M.; Record, E.; Ceccaldi, B.C.; Asther, M. (2002). A biotechnological process involving filamentous fungi to produce natural crystalline vanillin from maize bran. Appl. Biochem. Biotechnol. 102-103, 141-153.

45. Li, K.; Frost, J.W. (1998). Synthesis of vanillin from glucose, J. Am. Chem. Soc. 120, 10545-10546.

46. Lomascolo, A.; Stentelaire, C.; Asther, M.; Lesage-Meessen, L. (1999). Basidiomycetes as new biotechnological tools to generate natural aromatic flavours for the food industry. Trends Biotechnol. 17, 282-289.

47. Muheim, A.; Lerch, K. (1999). Towards a high-yield bioconversion of ferulic acid to vanillin. Appl. Microbiol. Biothechnol. 51, 456-461.

48. Müller, B.; Münch, T.; Muheim, A.; Wetli, M. (1998). A process for the production of vanillin. European Patent 0885968.

49. Narbad, A.; Gasson, M.J. (1998). Metabolism of ferulic acid to vanillin using a novel CoA-dependent pathway in a newly-isolated strain of Pseudomonas fluorescens. Microbiology 144, 1397-1405.

50. Overhage, J.; Priefert, H.; Steinbüchel, A. (1999). Biochemical and genetic analyses of ferulic acid catabolism in Pseudomonas sp. strain HR199. Appl. Environ. Microbiol. 65, 4837-4847.

51. Overhage, J.; Steinbüchel, A.; Priefert, H. (2003). Highly efficient biotransformation of eugenol to ferulic acid and further conversion to vanillin in recombinant strains of Escherichia coli. Appl. Environ. Microbiol. 69, 6569-6576.

52. Overhage, J.; Steinbüchel, A.; Priefert, H. (2006). Harnessing eugenol as a substrate for production of aromatic compounds with a recombinant strains of Amycolatopsis sp. HR167. J. Biotechnol. 125, 369-376.

53. Pak, F.E.; Gropper, S.; Dai, W.D.; Havkin-Frenkel, D.; Belanger, F.C. (2004). Characterization of a multifunctional methyltransferase from the orchid Vanilla planifolia. Plant Cell Rep. 22, 959-966.

54. Priefert, H.; Rabenhorst, J.; Steinbüchel, A. (2001). Biotechnological production of vanillin. Appl. Microbiol. Biotechnol. 56, 296-314.

55. Rabenhorst, J. (1996). Production of methoxyphenol-type natural aroma chemicals by biotransformation of eugenol with a new Pseudomonas sp. Appl. Microbiol. Biotechnol. 46, 470-474.

56. Rabenhorst, J.; Hopp, R. (2000). Process for the preparation of vanillin and suitable microorganisms. US. Pat. 6133003.

57. Raffellini, S; Guerrero, S.; Alzadora, S.M. (2004). Efecto del pH sobre la cinética de inactivación de Escherichia coli por peróxido de oxígeno. XIII Seminario Latinoamericano y del Caribe "Ciencia \& Tecnología de Alimentos". VII Jornadas Uruguayas. II Feria Especializada de
Ingredientes y Aditivos, Envases, Equipos y Servicios, Montevideo, Uruguay.

58. Ramachandra Rao, S.; Ravishankar, G.A. (2000). Vanilla flavour: production by conventional and biotechnological routes. J. Sci. Food. Agric. 80, 289-304.

59. Rito-Palomares M. (2004). Practical application of aqueous two-phase partition to process development for the recovery of biological products. J. Chrom. B 807, 3-11.

60. Rivas Torres, B.; Aliakbarian, N.; Torre, P.; Perego, P.; Domínguez, J.M.; Zilli, M., Converti A. (2009). Vanillin bioproduction from alkaline hydrolyzate of corn cob by Escherichia coli JM109/pBB1. Enzyme Microb.Tech. 44, 154-158.

61. Rosazza, J.P.N.; Huang, Z.; Dostal, L.; Volm, T.; Rosseau, B. (1995). Biocatalytic transformations of ferulic acid; an abundant aromatic natural product. J. Ind. Microbiol. Biotechnol. 15, 457-471.

62. Salter, G.J.; Kell, D.B. (1995). Solvent selection for whole cell biotransformations in organic media. Crit. Rev. Biotechnol. 15, 139-177.

63. Schlegel, H.G. (1996). Microbiologia, Zanichelli, Milan.

64. Schmid, A.; Kollmer, A.; Mathys, R.G.; Witholt, B. (1998). Developments toward large-scale bacterial processes in the presence of bulk amounts of organic solvents. Extremophiles 2, 249-256.

65. Schreier, P. (1992). Bioflavours: an overview. In: Patterson, R.L.S.; Charlwood, B.V.; MacLeo, G.; Williams, A.A. (eds.). Biotrasformation of Flavours. Cambridge, UK. The Royal Society of Chemistry, p. 1.

66. Sciubba, L.; Di Gioia, D.; Fava, F.; Gostoli, C. (2009). Membrane-based solvent extraction of vanillin in hollow fiber contactors. Desalination 241, 357-364.

67. Serra, S.; Fuganti, C.; Brenna, E. (2005). Biocatalytic preparation of natural flavours and fragrances. Trends Biotechnol. 23, 193-198.

68. Shin, H.D.; Chen, R.R. (2006). Production and characterization of a type B feruloyl esterase from Fusarium proliferatum NRRL 26517. Enzyme Microb. Technol. 38, 478-485.

69. Stentelaire, C.; Lesage-Meessen, L.; Delattre, M.; Haon, M.; Sgoilot, J.C.; Colonna Cecaldi, B.; Asther, M. (1998). By-passing of unwanted vanillyl alcohol formation using selective adsorbents to improve vanillin production with Phanerochaete chrysosporium. World J. Microbiol. Biotechnol. 14, 285-287.

70. Suresh, G.A.; Ravishankar (2005). Methyl jasmonate modulated biotrasformation of phenyl propanoids to vanillin related metabolites using Capsicum frutescens root cultures. Plant Physiol. Biochem. 43 (2) 125-131.

71. Sutherland, J.B.; Crawford, D.L.; Pometto III, A.L. (1983). Metabolism of cinnamic, $p$-coumaric and ferulic acids by Streptomyces setonii. Can. J. Microbiol. 29, 1253-1257.

72. Thibault, J.; Micard, V.; Renard, C.; Asther, M.; Delattre, M.; LesageMeessen, L.; Faulds, C.; Kroon, P.; Williamson, G.; Duarte, J.; Duarte, J.C.; Ceccaldi, B.C.; Tuohy, M.; Couteau, D.; Van Hulle, S.; HeldtHansen, H.-P. (1998). Fungal bioconversion of agricultural by-products to vanillin. LWT-Food Sci. Technol. 31, 530-536. 
73. Tomlinson, G.H.; Ibbert, H. (1936). Studies on lignin and related compounds. XXIV. The formation of vanillin from waste sulfite liquor. $J$. Am. Chem. Soc. 58, 345-348.

74. Torre, P.; Aliakbarian, B.; Rivas, B.; Domínguez, J.M.; Converti, A. (2008). Release of ferulic acid from corn cobs by alkaline hydrolysis. Biochem. Eng. J. 40, 500-506.

75. Torre, P., De Faveri, D., Perego, P., Converti, A., Barghini, P., Ruzzi, M., Faria, F.P. (2004). Selection of co-substrate and aeration conditions for vanillin production by E. coli JM109/pBB1. Food Technol. Biotechnol. 42, 193-196.

76. Torre, P., De Faveri, D., Perego, P., Ruzzi, M., Barghini, P., Gandolfi, R., Converti, A. (2004). Bioconversion of ferulate into vanillin by Escherichia coli strain JM109/pBB1 in an immobilized-cell reactor. Ann. Microbiol. 54, 517-527.

77. Torre, P.; Guarino, C.; Converti, A.; Barghini, P.; Ruzzi, M.; Sato, S. (2003). Effects of temperature and starting substrate concentration on ferulate-to-vanillin bioconversion by Escherichia coli JM109(pBB1). Farmácia \& Química 36 (3), 39-42.

78. Vaithanomsat, P.; Apiwatanapiwat, W. (2009). Feasibility study on vanillin production from Jatropha curcas stem using steam explosion as a pretreatment. Int. J. Chem. Biomolec. Eng. 2 (4), 211-214.

79. Van den Heuvel, R.R.H.; Fraaije, M.W.; Laane, C.; Van Berkel, W.J.H. (2001). Enzymatic synthesis of vanillin. J. Agric. Food Chem. 49, 2954 2958.

80. Vane, L.M. (2005). A review of pervaporation for product recovery from biomass fermentation processes. J. Chem. Technol. Biotechnol. 80, 603629.

81. Vega, J. (1993). Transformación de materiales lígnicos a compuestos de alto valor agregado. Seminario de Licenciatura, San José, CR, Laboratorio de Polímeros, Universidad de Costa Rica.

82. Walton, N.J.; Mayer, M.J.; Narbad, A. (2003). Vanillin. Phytochemistry $63,505-515$

83. Walton, N.J.; Narbad, A.; Faulds, C.B.; Williamson, G. (2000). Novel approaches to the biosynthesis of vanillin. Curr. Opin. Biotechnol. 11, 490-496.

84. Williamson, G.; Kroon, P.A.; Faulds, C.B. (1998). Hairy plant polysaccharides: a close shave with microbial esterases. Microbiology 144, 2011-2023.

85. Yoon, S.H.; Li, C.; Kim, J.-E.; Lee, S.-H.; Yoon, J.-Y.; Choi, M.-S.; Seo, W.-T.; Yang, J.-K.; Kim, J.-Y.; Kim S.-W. (2005). Production of vanillin by metabolically engineered Escherichia coli. Biotechnol. Lett. 27, 18291832.

86. Zabkova, M.; da Silva, E.A.B.; Rodrigues, A.E. (2007). Recovery of vanillin from lignin/vanillin mixture by using tubular ceramic ultrafiltration membranes. J. Membr. Sci. 301, 221-237.

87. Zhang, Q.F., Jiang, Z.T., Gao, H.J., Li, R. (2008). Recovery of vanillin from aqueous solutions using macroporous adsorption resins. Eur. Food Res. Technol. 226, 377-383.

88. Zheng, L.; Zheng, P.; Sun, Z.; Bai, Y.; Wang, J.; Guo X. (2007). Production of vanillin from waste residue of rice bran oil by Aspergillus niger and Pycnoporus cinnabarinus. Bioresour. Technol. 98, 1115-1119.

89. Zucchi, G.; Khan, J.A.; Vulfson, E.N. (1998). Could organic solvents be used for the alteration of flux of hydrophobic intermediates through a metabolic pathway in microorganisms? J. Microbiol. Biotechnol. 8, 719722 . 